\title{
'Vase of light': from the exceptional individuality to the individualisation process as influenced by Greek-Arabic cosmology in Albert the Great's Super Iohannem
}

\section{Introduction}

As we know, standard theories regard religious individualisation as a specifically modern or early modern phenomenon. The question today is whether we can find glimpses of religious individualisation also in pre-modern Europe, perhaps even connected with the dynamics of stabilisation or 'institutionalisation'. I shall focus in what follows on Albert the Great (1200-1280) and his treatment of the individual. This first appears in his commentary on the Gospel of John (Jn 1:6). The verse reads: 'A man came, sent from God, whose name was John (New English Translation).' Albert the Great highlights John, as witness of God, to be an exceptional individual. Paradoxically, Albert will raise this witness-figure to the rank of a universal model of individualisation. At the end of his commentary, he even invites every reader to become a witness of God in their own way (Casteigt forthcoming). This transformation of an exceptional individual to a model of individualisation happens through a series of textual processes. I would like to show here how Albert develops them by interlacing different philosophical and scientific traditions that enable this Christian character to reach a universal signification for every individual.

As a preliminary, I ought to clarify how I shall use here two main concepts.

The first one is imported from sociological studies. 'Institutionalisation', as processes through which individualisation forms are established, will in the frame of this philosophical inquiry be understood and described as modes of elaboration of textual series, and not as being embedded in social and political institutions. In this case, the dynamics of textual institutionalisation and its entanglement between Christian exegesis and Greek-Arabic cosmology and metaphysics results in an ambivalent, or even paradoxical, characteristic of religious individualisation. To become universal, the model of individualisation taken from John the Baptist goes through a de-personalisation of the individual, that is, an assimilation to non-human beings. This particular feature leads us to develop several meanings of the second main concept of our inquiry, i.e. individualisation. 
'Individualisation' will be regarded as religious inasmuch as the individual is always defined in this corpus of texts in relation to his or her divine principle. In the Super Iohannem, Albert the Great places his analysis on a metaphysical level. He does not consider here the political, social, or economic conditions of the institutionalisation of individualisation. In this context, 'individualisation' will be considered here as indicating a process which leads from the first meaning of the word in these passages of the Albertian works, through a second, and to a third meaning, which I synthetically present as three distinct steps.

First of all, 'individualisation' designates the circumscription, or description, of an individuality. Albert's description of the exceptionality of the first witness of the incarnate divine Word, John the Baptist, is based on John's singular properties as a person. According to this first meaning, Albert's understanding of individualisation - as the description of the unicity of an individuality - complies with the patristic tradition.

Secondly, the dynamics through which this mode of individualisation will be universalised potentially to all human beings entail a process of depersonalisation and assimilation to non-human agents. Thereby, an exceptional individual will become a model of religious individualisation through the mediation of the individuality of cosmic entities. These entities are non-human beings that can transmit light without producing it. In Greek-Arabic cosmology, such entities that do not produce the light that flows through them are stars, planets and their satellites. Albert figuratively calls 'vases of light', because their transparency allows them to spread the light of the sun that they receive. This second step of the 'institutionalisation' of individualisation opens a broader question: the one of the attribution of a common mode of agency to human and non-human beings. 'Agency' is used here as a common term for beings considered as intellectual entities, like the cosmological ones, without being specifically restricted to human agents. Therefore, 'religious individualisation' may serve as a productive heuristic tool for highlighting the interaction between the identity of an individual and his or her mode of operating as an agent. It helps heuristically to link the levels of being and of operation. In this perspective, individuals have to be considered at a larger scale than the personal one. They belong to a cosmos in which they interact and share their mode of operation with non-human agents.

Thirdly, 'individualisation' will be understood, through the cosmological image of the 'vase of light', as a possible universal pattern that concerns any individual as far as he or she is embodied. In this sense, 'individualisation' does not mean anymore an exceptional gift but rather a relational place between the divine principle and the other agents of the human and non-human community which enables the whole universe to continuously receive the light of the principle, even in its extreme parts. The embodied individual, who is then 'institutionalised' by 
this textual series of steps, has a relational function: he or she links up the divine principle to all creatures and enriches the manifestation of the principle with particular features based on his or her bodily constitution. Thus, the function of John as a pattern of individualisation is not directly to be understood as an ethical practical norm but rather as a metaphysical model in which the particular properties of individuality (in the first meaning) are reduced or theoretically suspended, so as to concentrate the attention on the being and on the agency of the individual as an embodied mediation of the causality of the first principle.

This modification process of the meanings of 'individualisation' occurs through the reception of the Greek-Arabic cosmology into the medieval biblical exegesis, so that the interlacing of different religious traditions changes Albert's comprehension of the Gospel of John as a fundamental text for the Christian tradition. With these references to the Greek-Arabic cosmology, the Doctor universalis gives, indeed, a new interpretation of the Johannine witness: a witness is not confined to exceptional personalities but, more generally, he or she is to be understood as a mediation which, similarly to a 'vase of light', manifests the principle indirectly, transmitting the light of the principle itself to others who cannot have direct access to it. But he or she does not carry on a mere transparent diffusion of the light. The witness colours the ray that he or she receives with the particular quality of his or her own individuality. And this qualification by his or her individuality relies on the specific physical composition of his or her body. Thereby, the Dominican master opens a new possibility to understanding individualisation in the Christian tradition. In this third step of the dynamics of individualisation, even though Albert the Great offers a universal model of individualisation, such an individual is still characterised by his or her particular body. And this body has a religious function: it manifests the divine principle in an absolutely singular manner.

From the viewpoint of the textual corpus and of the method we will follow, I shall focus on the exegesis of John 1:7 ('He came as a witness to testify about the light, so that everyone might believe through him', New English Translation) and on the textual network around the figure of the 'vase of light'. It will appear that the 'vase of light' constitutes a figural unity in Albertian thought which crosses his entire works, connecting different textual corpora of commented texts (Aristotelian, Dionysian, biblical) and various disciplines. As a first step, I shall develop the first meaning of 'individualisation' and its institutionalisation strategy by elucidating how Albert the Great interprets the traditional explanation of the characteristics of any witness according to the Fathers of the Church. As a second step, I shall show how Albert builds a new model of 'individualisation' using the image of the 'vase of light'. Both the second and the third phases of the process of individualisation that we will distinguish belong to the Albertian interpretation of the 
Greek-Arabic cosmological texts about the 'vase of light' and allow Albert to give a new interpretation of the Johannine witness and of the individual represented by the witness.

\section{Individualisation as the description of an exceptional personality}

As a preliminary, I owe the reader an explanation about why I have chosen this textual corpus and this particular case. The Gospel of John belongs to the set of revealed holy texts of the Christian tradition. As the fourth Gospel was the last work that, in the Middle Ages, a master of theology should comment on according to the order of studies in the Latin Universities, it offered, therefore, the occasion to make a synthesis between the different philosophical traditions that a master had commented on in his career and the various texts of the Bible that he had examined as an exegete. That is why Albert the Great's Super Iohannem represents a major speculative work, so as to observe how he binds together the reception of Greek-Arabic philosophy and the Christian tradition, at the end of the thirteenth century in the Latin world.

Therefore, from a methodological point of view, we will be particularly careful in looking at the way Albert interlaces the patristic sources with the GreekArabic ones for the first meaning of 'individualisation'. The manner in which the Doctor magnus comments on his sources builds a textual series in a particular literary genre: the exegetical one. These textual series reflect the speculative work he pursues throughout his biblical commentary about the different types of individualisation. It is, therefore, possible to distinguish two different typologies. The first meaning of 'individualisation', that is the description of an exceptional personality, is elaborated by an 'architectonical' network of mustered individual aspects and implicit patristic sources, whereas the second and third meanings of 'individualisation' lean on a dynamic typology. The reader must cross the whole of the Albertian works and its textual treatment of the 'vase of light' to understand what the new model of 'individualisation' means. The first typology proceeds by juxtaposition of criteria, the second by dynamic development of a unique model that is expressed through an image.

As for the first meaning of 'individualisation', at the beginning of his exposition of the verse Jn 1:7, Albert the Great explains clearly the aim of the verse as he understands it: in that verse, 'the witness is praised, and he is shown omni exceptione maior (Lewis, Short 1956)' (Albertus 2019, 106, 6). Albert uses here a specific juridical terminology that means that this witness, John the Baptist, is 
greater than anything which could limit his testimony. There are four reasons for him being a witness beyond reproach and suspicion: his nature, his function as a witness, the authority of the one who sends him, that is God himself, and the meaning of his name (ibid., 106, 14-7).

The first reason is his human nature that makes him appropriate not only to his human addressees but also to the divine Word made flesh (ibid., 106, 22-108, 4) whom he testifies. So his exceptional reliability rests on the fact that he, as a human being and not as an angel (ibid., 108, 5-6), is an adequate mediation for both terms of the relationship. No divine mediator would suitably communicate with human beings except the one who is the Word made flesh. But the witness needs to share the very nature of his addressees, just as the pontiff is chosen among men as a mediator between them and God, according to the example that the Doctor magnus gives. About this first reason, the Master of Cologne does not claim any novelty of his thesis: he explicitly quotes the Glossa ordinaria (Glossa 1603, 1024), a miscellany of biblical glosses of the Fathers of the Church, and comments on it.

The second reason is John's function as being sent (Albertus 2019, 108, 9-14). 'Being sent' etymologically means that he is not an angel by nature but by function: he announces the Word made flesh. He comes neither from his own authority nor from the authority of other human beings or by their mediation. But he receives his mission from God himself (not the incarnate God): that is the third reason for his absolute reliability (ibid., 108, 15-8) as a witness. Both the second and the third reasons are founded upon several biblical quotations.

The fourth reason is the witness' name (ibid., 108, 19-23) and its meaning. The name 'John' was not chosen by his parents. Otherwise, their newborn son should have taken the name of his father: Zechariah. His name was given by God and, as a reflection of this divine origin, it means in itself grace or divine gift. The Gloss which Albert of Cologne explicitly refers to adds: 'substantially given'. In other words, John's identity consists substantially in the grace of God. The Doctor magnus insists on placing John's whole life from the beginning under the sign of God's gift: from the announcement to his father, his conception in the womb of the old Elizabeth.... Albert writes also that John's father was God. Thereby, he means: the one who gave John his name. But the scriptors of the manuscripts of Düsseldorf (Albertus 1455), Emmerich (Albertus 1476), Köln (Albertus 1450-1455) and the printed editions (Albertus 1477; 1504-1505; 1651; 1899), who perfectly well knew that John's father was Zechariah, corrected pater to patet, so that the text does not mean anymore: 'the father, the way he [John] was made, the nature of John and his mission are referred to God' (Albertus 2019, 112, 3-4) but 'it is evident that the way he was made, the nature of John and his mission are referred to God'. These later corrections made by the scriptors of the manuscripts show how 
Albert's interpretation - that the whole being of John comes from God, understood as his father - still was new and difficult to accept even in the fifteenth century.

Moreover, the Doctor magnus emphasises that the identity of John consists substantially in the divine gift, with the verse 1 Cor. 15:10 ('By God's grace, I am what I am etc.'). Thereby, he suggests an identification between Paul of Tarsus and John the Baptist on the very point of their whole identity being given by God, in as much as they are sent by him and have accepted their mission.

Thus, what makes John the Baptist an exceptional witness is, firstly, that he is a human being whose nature ensures him to be an appropriate mediation between the incarnate Word and his human addressees; secondly, that he does not come from any human authority; thirdly, that he has been sent by God and that does not add any human intention to the divine mission he receives; and fourthly, that, as being sent, his whole identity substantially consists in his divine mission.

Through the networks of biblical verses he quotes, Master Albert makes clear that John shares certain aspects of his exceptionality, as a witness, with other biblical characters ${ }^{1}$ (Albertus 2019, 112, 1-4). The Albertian method of interpretation of the Christian Holy Scriptures consists in elaborating echoes and resonances between some aspects of certain biblical figures. These figures correspond to each other and contribute to a constant rewriting and modifying of the story of the People of God. But also the Prologue which the Doctor magnus writes to his own Super Iohannem creates an overlay between two different persons named John: the Evangelist and the Baptist. Under the following aspects both John the Baptist

1 With any Pontiff, according to He. 5:1; with the Patriarch Abraham as a man according to Gen 18:27; as a sent man, with Obadiah 1:3; with Is. 48:16 and with Moses in Ex. 3:13 as sent from God; with Paul in 1 Co. 15:10 as receiving substantially his identity from God. And when Albert the Great refers to another translation which links every aspect of John's life to God, he adds some more identifications to other biblical figures. This alternative translation of the verse is so: 'This exposition is confirmed by another translation that says so: "He has been made man, he has been sent by God, his name was John”.' The Doctor universalis distinguishes between three aspects with regard to the first criterium: his father, the way he was made and his nature: 'For this reason, John's father, the way he was made, his nature and [his] mission are referred to God.' And the name 'John' indicates this original relationship to God in the womb of John's mother, which assimilates him to Jesaiah in Is. 49:1: 'The Lord has called me from my mother's bosom etc.' and to Jeremiah in Jr 1:5: 'Before I made you in the motherly bosom, I have known you, and before you came out of the motherly bosom, I have sanctified you.' In relation to John's mission in this second translation, Albertus Magnus likens John the Baptist to Paul in Gal. 1:11-12: 'I have let you know the gospel that has been announced to me, because it is not according to man. And I have neither indeed received it nor learnt from a man, but from Jesus Christ's revelation' and to Jr 1:7: 'You will go to all that I will sent you to, and you will tell them that I shall command to you.' 
and John the Evangelist overlap implicitly. As for the authority who sends the witness, the Doctor universalis writes that the divine Wisdom itself manifests in the increated Word and in the Word made flesh and is the first efficient cause that teaches John the Evangelist and moves him to write (Albertus 1899, 7-8). So John the Evangelist, like John the Baptist, neither speaks from his own authority nor because he is sent by human beings. He is sent by God (ibid., 12b) and the spirit of the Wisdom speaks in and through him, so that the authority of what he writes is indubitable, says Albert, commenting on Mt 10:20 (ibid., 8) about the fourth Evangelist. Regarding the name 'John', the Doctor magnus follows the commentary of Jerome of Stridon and understands this name as meaning the grace of God, which indicates a person in whom grace is or to whom a divine gift is made (ibid., 11b). Thanks to the similarity of these features, both John the Evangelist and the Baptist are described, on the one hand, as exceptional individuals and, on the other, as overlapping figures. Their singularity can, under certain aspects, build a general type of individuality.

Therefore, on a more general level, we could conclude from this first definition of the individuality of the witness that he or she corresponds to a singular case whose outstanding properties could be yet granted to other exceptional biblical figures. The exceptionality of this individual is paradoxically conceived as general or, at least, as sharable by others. As far as his or her nature is concerned, the witness is a human being, so that he or she can communicate what the Word made man (humanatum) is to his or her human addressees. Relating to his or her mission as a witness sent from God as well as to the name 'John', the conception of the individual consists in shifting the substance of the human individuality from its contingent singularity towards its divine origin. The human individual in his or her own being substantially consists in the gift of God, that is, in the relationship with God. It is, therefore, a relational conception of the substance, or of the being, that is applied here to the understanding of the individual. Hence, the exceptional individual is the one whose characteristic is to receive his or her being (pointed out by the name 'John' in the case of John the Baptist) and the reason for his or her action only from the divine principle. The singularity of these exceptional witnesses of God rests on a detachment from their own particular qualities as this or that concrete person. They are in a sense unexceptional, because their identity as individuals substantially consists in what all individuals share, that is the universal metaphysical origin of a first cause of being and acting. But their identity is not circumscribed by the particular features that usually describe the contingent conditions of a personal existence. So the textual 'institutionalisation' of the figure of the individual consists, in this first step, in elaborating a category of individuals who are exceptional because they have left behind all the particular features of their particular identity determined in space and time. This process of textual 
'institutionalisation' is inherited from the patristic tradition which is here referred to very generally as the Gloss. This textual process uses an overlapping technique that consists in putting into relief some similar features that enable linking together different biblical figures. Yet, Albertus Magnus sharpens this patristic technique, concentrating it in a metaphysical formula about the identity of the witness.

In contrast with those exceptional individuals, the interlacing of the exegesis of the Gospel of John with the Greek-Arabic cosmology could make one think, at first sight, of a universalisation of the role of the witness who receives a specific function in the cosmos. Yet I shall argue here that an accurate reading of how the Albertian text really operates has led us to discover that the universalisation, as a detachment from the properties of an individual who exists in a particular space and time, is already involved in the original interpretation that Albert develops leaning on the inheritance of the patristic tradition: the identity of such an individual consists in defining itself substantially as coming only from his or her divine principle. What the Greek-Arabic cosmology brings to the Master of Cologne is, therefore, more specifically the identification of such individuals with non-human agents.

\section{The identification of the individual with non-human agents through the influence of Greek-Arabic cosmology}

In his commentary on Jn 1:8a ('This one was not the light'), Albert the Great compares John the Baptist to a 'vase of light'. According to the words of the Gospel of John, John the Baptist is not the true light that, as a source of illumination, illuminates from itself. Such a true light corresponds only to Christ. But John is identified to an illuminated light (Albertus 2019, 120, 19-20), that is a light that illuminates because it receives its own light from the source of light itself. Albert's aim is to strongly underline the Evangelist's insistence upon 'the distinction between the one who gives testimony and the one whom he bears witness to' (ibid., 120, 11-12), that is, between John and Christ. It follows that human individuals are not prime agents. They receive their capacity to act from a divine principle that is the universal cause of action. In what follows I shall demonstrate that the witness represents a type of agency that is at the same time secondary with regard to the first cause and immediate, as long as it transmits the whole virtue of the first cause itself. This type of agency corresponds, in the Albertian system, to the specific function of a mediation that does not communicate only a reduced part of what it receives, contrarily to a conception of causality in terms of participation. 
The argument of the lux illuminata is already in the Gloss on Jn 1:8 and in Augustine's commentary on the Gospel of John (Augustinus 1954, 10, 9-11). But the Doctor magnus does not refer to either of those sources here, although he has quoted the Gloss explicitly about John the Baptist, as we have seen. Rather, later on in the exegesis of $J n$ 1:8a, he refers to Avicenna. And he uses the expression 'vase of light', in order to answer to a wrong understanding of the verse Jn 1:8a which would, according to him, derive from Avicenna's interpretation of lux in his Liber de anima (Avicenna 1972, 170, 7-171, 22). The Albertian choice to explicitly rely upon an Arabic source rather than the Fathers of the Church underlines the core of his philosophical gesture: he draws from non-Christian traditions, in order to universalise the function of the Christian witness as a metaphysical mediation and to found it on rational arguments.

According to Avicenna, lux means only the 'light in [its] own nature and that is not illuminated' (Albertus 2019, 122, 1-2), that is to say only an active principle. Therefore, Avicenna would contradict the Albertian exegesis of this verse, namely: 'The good are the illuminated light, but the illuminating light, which is Christ, is different' (ibid., 120, 19-20). Avicenna would deny the distinction between two types of light and would interpret the verse Jn 1:8a as follows: 'The good are the light that illuminates and that is not only illuminated' (ibid., 122, 2-4). Moreover, Albert refers to the evidence of biblical authorities such as $M t$ 5:16 to strengthen what would be Avicenna's interpretation of the verse. So, according to Avicenna and to this passage of the Holy Scriptures, John the Baptist should be an active principle of illumination, rather than passive, and would be, then, identified with Christ.

Avicenna's interpretation of lux as only active constitutes an objection to the exegesis of Jn 1:8a that the Doctor universalis first gave. To rebut this argument, Albert makes explicit his identification between the witness as an illuminated light and the specific function of mediation as a 'vase of light'. He develops the distinction between the two types of light that he has already introduced at the beginning of the exegesis of $J n$ 1:8a: the divine source of light which is only active and another one which illuminates, because it is illuminated. This second type of light, which is receptive, corresponds to John and to the category of perfect human beings (ibid., 122, 5-10) to which John belongs. We shall come back to this category of perfect individuals in the third step of our inquiry. Let us concentrate now on their comparison with an illuminated light. These active and passive functions of illuminating and being illuminated are assimilated to what the Doctor expertus calls a 'vase of light'. To illustrate this expression, he gives the example of a 'luminary that emanates the light that is infused to him' (ibid., 122, 9).

The comparison with luminaries - that is with cosmological entities - is not new. Albert the Great quotes two occurrences in the Holy Scriptures that mention the luminary (ibid., 98, 21; 122, 9-10). But Albert's interpretation comes from 
the understanding of the luminary as a 'receptacle of light' by John Damascene (Damascene 1955, 86, 1-2). The Doctor magnus characterises this receptive function noted by Damascene as a 'vase of light'. As the 'vase of light' is a receptacle, it corresponds to the physical and metaphysical function of the matter, that is, the passive term in a relation, within the meaning of being receptive. Therefore, a 'vase of light' is, in Albert's eyes, a body that is composed of a formal principle, the light that it receives, and a material one, the capacity to receive the light and to be informed by it. 'A luminary is, namely, as the Damascene says, a "vase of light" and so there must be in it a composition of light (luminis) and of a body that holds the light (lumen)' (Albertus 1993b, 235, 27-30).

Because this capacity to receive characterises precisely a body, a personal individual can be easily compared to a 'vase of light' and, therefore, to an impersonal being, like a cosmic entity. The mode of operation of such a nonhuman agent consists in both receiving the light from the source of illumination which is, in this cosmological (Duhem 1954, 327-45; Hoßfeld 1969, 318-29; Price 396-436; Stein 1944, 182-91; Gregory 1996, 1-23) monarchical² system unique, and in transmitting it to others. According to Isidore of Seville (Isidorus 1850, 178b; 1911, without pagination) whom the Doctor universalis follows (Albertus $1980,90,28 ; 1972,65,1)$, the etymology of solis is solus lucens: the sun is the only entity that shines from itself and possesses light in itself. The moon and the stars don't have light in themselves. They acquire it from the sun (ibid., 90, 28-30).

Therefore, perfect human beings are not anymore merely described as exceptional individuals. Rather, they are identified with the general function of a body that is able to receive the light of the source of illumination, so as to transmit it to others (Albertus 1993b, 235, 42-4). This identification with non-human agents, the cosmic entities, leads us to examine, firstly, their specific mode of agency and, secondly, their status as embodied individuals.

\subsection{The mode of agency of non-personal entities}

In assimilating the personal individual to a non-human agent, Albertus Magnus focuses attention on their common mode of agency. The first characteristic of the operating mode of a 'vase of light' consists, namely, in receiving the light of

2 'Monarchical' is here understood in its etymological meaning, denoting what has a unique principle. Albert makes clear that the comparison between the sun and God, as first cause, is only an analogy between a creature and the creator, which includes an immeasurable disproportion. 
the sun from which all the bodies in the universe receive their light univocally (Albertus 1972, 64, 49-54), that is according to precisely the same nature and definition, be they superior or inferior bodies. On this argument of the univocal presence of the light in every cosmic body, the Doctor magnus follows the authority of Aristotle and of other philosophers (Aristoteles, Metaph., lib. 2, cap. 1 (993b 24-7) in Ps.-Aristoteles 1562-1574, 283b; Avicenna 1980, 311, 9-15) he anonymously mentions. If all cosmic bodies receive the same nature of light, therefore this light must come from a first source. That means that all other bodies that emit light receive from the sun the light they give out. So the first characteristic of the mode of agency of non-human entities is to be receptive with regard to the first universal agent, which is the first cause. This feature precisely meets the definition of John as an exceptional personal individual: as cosmic bodies receive the whole light they transmit from a unique luminous source, the sun, so John is sent by God only and receives from God only his own being and capacity to act as a witness.

The second characteristic of the mode of agency of a 'vase of light' corresponds to John's identity substantially consisting in being received from God. We shall observe how the comparison with cosmic entities enables Albert the Great to universalise this ontological definition and to specify it on the level of the mode of operation. The second feature of the mode of agency of the "vases of light' is that they operate on the basis of their own being, and not only as an accident (a non-essential element) regarding what they are. The comparison with non-personal entities leads the Doctor magnus to define the being of an individual through his or her action and, reciprocally, to link his or her action to his or her ontological constitution as an individual. The transition from the reception of the sunlight to its transmission happens, namely, through the ontological transformation of the cosmic body. Albert writes that the cosmic body receives 'in its depth' (Albertus 1971, 154, 26-33; 107, 39-46; Albertus 1980, 90, 57-91, 4; Albertus 1975, 57, 1-2) the light that passes through it, so that this body entirely enters into fusion with the light (Albertus 1975, 56, 71-57, 7; Avicenna 1972, 260, 95-263, 54, spec. 263, 44-54). The Master of Cologne points out that to receive light 'in one's depth' means to welcome it according to one's own being (Albertus 1972, 64, 55-6). This melting of all its parts radically transforms its own being as material body into a luminous being. This happens to this body through its being 'trampled' (calcatio) until it reaches fusion. In other words, it was only a physical body with specific transparent properties that particularly enable it to receive and transmit the light of the sun. And now it becomes in actu a bright light transmitter. Comparing the personal individual with a non-human agent, Albert the Great highlights that the mode of agency of an individual in general fundamentally arises from the transformation of his or her own being that is performed by the 
first universal agent. The definition of his or her being as individual depends on the permanent flowing of the active power of the first cause through him or her that makes him or her able to illuminate.

The third characteristic of the operating mode of the 'vase of light' concerns the final cause of this operation. The aim of the emission of light from the sun is to illuminate the whole universe as deeply and completely as it can, according to the measure in which the various bodies can receive it. So light is this instrument through which the sun, or first motor, attracts every inferior body and leads it towards its own form, or being in actu, that is the very nature of light itself (ibid., 65, 7-9). Some bodies remain dark and opaque. Others refract light outwardly or superficially, as we will see below. Yet, the 'vases of light' are totally transformed in light. That is why they acquire a specific function as mediations that convey the light of the sun without reduction. Hence, through this fusion, the first motor assimilates to itself some specific cosmic bodies, transforming them into 'vases of light' which are able to transmit at their turn the light of the principle. But they are not merely channels that remain independent from the light that passes through them, assuming this transmission only as a role that would not affect their identity. As 'vases', they retain in some way the light they welcome, so that the sunlight becomes their own form, or definition, as individuals. The Doctor universalis even speaks of them 'soaking' (Albertus 1980, 78, 7-11) up the light of the sun until the light reaches their own centre. Yet, their being-light - that is, being of the same nature of the light of the sun - indicates their essential and continuous dependence upon the sun, as the source of light. They can transmit light further on, because this act can constantly be led back to the first motor (Albertus 1993a, 107, 68-71) as the principle that constitutes them. Their being in $a c t u$, that is in the operation of transmitting light, consists in drawing continuously light from its source (ibid., 107, 73-6). And this act of drawing light, melting and emitting it, forms their own being as 'vases of light': the being of luminaries is constituted by the light of the sun itself (ibid., 43, 1-3 and 14-23).

This conception of the identity of non-human entities rejoins here the identity of exceptional human individuals, like John the Baptist and John the Evangelist. Both are paradoxical types of individualisation. The identity of the personal and non-personal entities is not defined by their particular features but only by the universal ones, namely that they receive their being and their operation from the first principle. Yet, with the comparison of the exceptional witnesses of God with non-human agents, Albert the Great now focuses this conception of individual identity on the mode of agency that is intimately related to the being of the agent. He bases this conception on the arguments of the Philosophers and can thus generalise it. 


\subsection{Embodied individuals}

Now, the Master of Cologne does not make explicit why he uses exceptional individuals and specific cosmic bodies as a model of individualisation which could have a normative value for everyone - in the conclusion, we shall make explicit the nature of 'normativity' here. The function of the 'vase of light' is both cosmic and metaphysical. It corresponds to the function of a mediation which prevents a metaphysical system from being, on the one hand, pantheistic (Albertus 1993a, 45, 52-6) and, on the other, monistic. According to the first modality, the principle would be confused with the universality of the beings it produces. According to the second, all the individuals would melt their differences in the unique nature of the principle. Albertus Magnus wants to avoid such metaphysical modalities that eliminate the possibility for the divine principle and the individuals to be differentiated.

Therefore, he insists on establishing specific mediations which are able to transmit the nature of the first principle itself, on the one hand, and on the other, leave a free space for the constitution of individual differences, because they signify a distance - or a difference - between the principle and the individual beings. In other words, such mediations allow, on the one hand, the unity of a differentiated universe. The Philosophers (De epistula de principio universi esse, cf. Libera 1990a, 55-78; Libera 1990b, 356-64; Libera 2005, 74-87; Aristoteles 1986, 74, 16-7; Alfarabius 1836, 47; Avicenna 1980, 481, 50-1; Averroes 1562-1574, 344b; Algazel 1933, 117, 33-4; 119, 10-1; 24-6; Maimonides 1520, 53; Avicebron 1892-1895, 113, 23-114, 6) express this conception of the universe as a totality 'turned towards the One' (uni-versum), which Albert describes as follows: 'from the simple One immediately arises only the One according to the order of nature' (Albertus 1993a, 55, 72-6). This conception of the unity that spreads immediately from the first principle towards the extremities of the universe rejoins the univocal transmission of the light of the sun, which we have mentioned above.

On the other hand, such mediations open the possibility for a differentiated order with different degrees (ibid., 55, 65-7). Depending on their greater or lesser distance from the first principle, each body receives the unique nature of the sun light differently, namely, according to its own capacity to receive. Therefore, the exceptional individuals or the 'vases of light' as specific cosmic bodies can be used as universal models of individualisation, because they indicate the fundamental nature of every agent, human or non-human: that is to receive one's being and one's operation entirely from the first principle. And, thus, they can serve as mediations that prevent confusion between the first principle and all individual beings. Yet, the comparison with the 'vases of light' points out that these specific 
agents are not universal beings that would only be defined by the light of the sun, but are embodied individuals.

As a fourth characteristic, the mode of operation of these impersonal agents is linked to them having a specific 'substance of body' (Albertus 1980, 90, 60-1) which differs from that of the sun and of the other bodies. The reason why a body receives and, to some extent, retains the light of the sun is its own consistence, its 'thickness' (Albertus 1971, 107, 38-9), as the Doctor magnus writes. He goes further: light is no property of the fire in itself. The fire receives light, when it is mixed up with a transparent body that has some thickness (Albertus 1971, 107, 29-32). In other words, light wouldn't shine and appear to us, if it weren't reflected upon a body and received by it. It would just dazzle and blind. That the individual agent is embodied is, namely, the condition for the light of the sun to be seen.

Yet, bodies receive the light of the sun singularly according to their relation to the source of light. The Doctor universalis, following 'men who excel in philosophy' - Aristotle (Ps.-Aristoteles 1562-1574, 283b), Ptolemy (Ptolemaeus 1515, 35v), Avicenna (Avicenna 1980, 311, 9-15), Messelach (Thorndike 1949, 354) and many others (e.g. Al-Bitrûjî 1952, 90, 4-5; 128, 30-129, 14) - distinguishes several degrees of reception (Albertus 1980, 90, 44-57). Jupiter (Albertus 1971, 154, 986, esp. 32) is from all sides crossed by the light of the sun and is, thus, resplendent. Because the body of Mars is of a less noble nature, the light it transmits declines towards red. The light that Venus emits is pale. And the light that passes through Saturn is even more pallid. The light of the moon seems to be veiled, because the moon is earthly (Aristoteles 1966, 152, 12-5) and opaque and because, depending on its phases, it gets away from a perpendicular position with regard to the sun (Albertus 1993a, 107, 77-88). Being embodied agents allows the different 'vases of light' to grant various shades to the light of the sun. Without each of these singular bodies, the light of the sun wouldn't have been manifested under those frequencies of the light spectrum.

The comparison with the 'vase of light' enables the Doctor universalis to link together the being and the agency of the individual as entirely received from the divine principle, on the one hand. And, on the other, it points out the absolute singularity of the way in which an embodied individual transmits what he or she receives from the first principle. This absolute singularity is based on his or her being embodied, which acquires here the status of a metaphysical function. In his commentary on the Gospel of John, Albert of Cologne derives, namely from a comparison of the ways in which the different cosmic bodies receive the light of the sun, a typology of the different ways a heart relates to the spiritual light (Albertus 2019, 98, 3-23). The embodied agency of the witness does not appear in the description of the exceptional individual influenced by the patristic tradition. 
By contrast, it constitutes a main characteristic of the mode of agency of the 'vase of light'. Therefore, Albert the Great clearly interprets the Gospel of John relying on this Greek-Arabic cosmological theory. He explicitly compares perfect human beings (ibid., 122, 7-8) like John to the 'vases of light', which are transparent and yet receive the light of the sun 'in their depth', that is being modified in their own being. They differ from the bodies that only receive light superficially and have, therefore, a shine that has only an outer beauty. They are also different from the black or opaque bodies that do not receive light, except as the manifestation of their own darkness.

\section{As a conclusion}

A closer reading of Albert's texts has revealed that, in the first type of individualisation, that is, in the patristic description of an exceptional individual, Albert's original interpretation consists in introducing already a universalisation dynamic. The Master of Cologne transforms the patristic conception of the exceptional witnesses of God, interpreting these witnesses as individuals who receive their whole being from God. What makes them exceptional is precisely what takes them away from their unicity as particular persons existing in a certain time and space.

Therefore, the function of the comparison with the 'vases of light' is not only to reinforce the universalised reach of the patristic type of individuality. But also, the assimilation of personal individuals to non-personal cosmic entities enables Albert to highlight their common mode of agency as embodied beings. Their mode of operation gives them the status of mediations of the first principle with regard to all other entities in the universe, because they receive inwardly the flow of the first principle which grants them being and agency, so that they are transformed in this active principle which constitutes their being as mediations, or 'vases of light'. Their embodiment enables them to transmit, at their turn, the light they receive, without reducing it and in a singular manner that depends on their physical constitution.

Thus, the second and third meanings of 'individualisation' - which are also two steps in an individualisation process, that is 'individualisation' as depersonalisation and as embodiment - which Albert the Great derives from his interpretation of the Greek-Arabic cosmology, enable him: to base his interpretation on philosophical arguments in speaking about exceptional individuals whose being and acting are only defined by the divine gift; to focus on the close relationship between those individuals' being and their operating; and to assign a specific metaphysical function of mediation to those individuals. 
That is why the Doctor universalis attaches a normative value to this cosmological pattern, or more precisely a protreptic function: every reader of his commentary on the Gospel of John is invited to go through this individualisation process, so as to match his or her mode of agency and the conception of his or her own identity to the mediating function he or she occupies in the universe between the divine principle and his or her own human community. Albert concludes his own commentary, following John the Evangelist himself, by calling on his reader to become, at his or her turn, a witness in his or her own way: that is an embodied individual who transmits in his or her own singular mode what he or she receives from the divine principle to his or her human addressees, constituting thereby (through his or her individualisation in actu) a community of individuals. Of course, human beings, as created, participate the light of the first causes. They do not convey it to others without reducing it. Yet, Albert's interpretation of the 'vase of light' has a protreptic function, in that it invites the reader to turn himself or herself towards this specific definition of his or her own being and agency. It does not mean that the definition of the individual as a participation of the first cause, which only receives being and capacity to act according to its limited capacity, is denied. Rather, Albert the Great suggests a plurality of perspectives on the comprehension of individuality. The protreptic function of the 'vase of light' underlines one of those perspectives that the reader can take into consideration.

The way in which the Master of Cologne himself goes through the individualisation process that leads to the 'vase of light' is reflected in the function he gives to this individualisation process in his own philosophical system, on the one hand, and, on the other, in the way he deals with the different rationalities involved in his act of commenting. Far from subordinating his hermeneutics to a corpus of theological dogmas, so as to constitute a 'Christian philosophy' according to Étienne Gilson's formula (Gilson 1998, 1-38), Albert extends Johannism beyond the limits in which the traditional exegesis of the Fathers of the Church had circumscribed it. Johannism is instead conceived under the influence of concepts forged inside exogenous sciences and under non-Christian authorities, such as Alfarabi, Avicenna, Averroes, Messelach and Ptolemy.

This interlacing of various religious traditions, scientific disciplines and realms of realities that allows this original interpretation of the Johannine witness is not a minor phenomenon in Albert's way of thinking. On the contrary, it leads to a central notion in Albert's philosophical system. The function of the mediation that entirely communicates the flow of the principle protects Albert's 'metaphysics of fluxus' from both monism and pantheism. Therefore, the individualisation process that Albert understands under the name 'vase of light' is raised as a philosophical tool that prevents all individuals from being assimilated to the divine substance or confused with it, on the one hand, and, on the 
other, that prevents the divine principle from being identified with individuals and reduced to them. With such mediations as 'vases of light', the first principle is present to every entity in the universe, even the farthest.

Albert was one of the first Dominican exegetes in the thirteenth century to receive the inheritance of the Greek-Arabic philosophy and sciences and to cross it with his own understanding of the Holy Scriptures and with their Greek-Latin patristic interpretations. At the studium of Cologne, he founds a new stream of interpretation in which one of the main principles is that the same truth lies at the origin of every religious tradition (Pagan, Jewish, Christian, Muslim...), which we can also find in Eckhart's works (Echardus 1936-1989, 154, 14-155, 2; 155, 5-7).

Moreover, the enhanced diffusion of the Albertian comprehension of this process of individualisation is documented in Eckhart's reading of the same passage of the Gospel of John (Casteigt 2014, 159-76). Meister Eckhart likens the fulfilment of the witness to the birth of a son. In other words, the mediation, or the witness, achieves its being in actu in an immediacy to the principle. The son has the same being as the father. He is only distinct from the father, as far as their relation is concerned, as the one who is begotten is different from the one who begets. But the subtlety of Eckhart's interpretation is that the son has the same mode of agency as a 'vase of light'. Identical to the nature of the principle, he transmits the very light of the principle without reducing it. Eckhart insists on the transparency of the agent, whereas Albert highlights the embodiment that makes the operation of the agent unique.

Albert the Great does not only look for homologous structures in the different religious traditions and ways of thinking; he does not merely modify the literary exegetical genre which will, for example in Eckhart's works, naturally include the 'external' influences of other disciplines of knowledge and other religious traditions; but rather he, as an author, goes through a specific process of de-personalisation and embodiment. In other words, his individualisation, as an author, is not limited to the criteria of the particular religious tradition to which he belongs. But his receiving of other religious traditions and assimilating them moves him off-centre from the place of exceptional individuality he occupies as a master in his religious order, the Order of Preachers, and in the intellectual institutions of his time. Through this de-personalisation, he experiences theoretically (through the commentaries of Greek-Arabic cosmological and metaphysical texts in this case) and practically, through the process of writing, an individualisation as a procedure which is opened to everyone as a possibility and as part of a development which is not only reserved for human agents but includes also nonhuman ones. Indeed, the model of individualisation is the one in which a star or a planet actualises transmission, through the singularity of its own physical body, of the light of the sun to the whole universe. 


\section{References}

\section{Sources}

Al-Bitrûjî. 1952. De motibus celorum, ed. F. J. Carmody. Abbeville: Berkeley University of California Press.

Albertus Magnus. 1971. De caelo et mundo, ed. P. Hoßfeld, Ed. Colon. V/1. Münster: Aschendorff.

Albertus Magnus. 1993a. De causis et processu universitatis a prima causa, ed. W. Fauser, Ed. Colon. XVII/2. Münster: Aschendorff.

Albertus Magnus. 1980. De causis proprietatum elementorum, ed. P. Hoßfeld, Ed. Colon. V/2. Münster: Aschendorff.

Albertus Magnus. 1899. Enarrationes in loannem in Beati Alberti Magni Ratisponensis Episcopi, Ordinis Praedicatorum Opera omnia, eds. A., $\mathbb{A}$. Borgnet, tome XXIV. Parisiis: Vivès.

Albertus Magnus. 1975. Problemata determinata, ed. I. A. Weisheipl, Ed. Colon. XVII/1. Münster: Aschendorff.

Albertus Magnus. 1993b. Super Dionysium De caelesti hierarchia, eds. P. Simon, W. Kübel, Ed. Colon. XXXVI/1. Münster: Aschendorff.

Albertus Magnus. 1972. Super Dionysium De divinis nominibus, ed. P. Simon, Ed. Colon. XXXVII/1. Münster: Aschendorff.

Albertus Magnus. 2019. Super Iohannem (Ioh. 1, 1-18), ed. J. Casteigt. Eckhart: Texts and studies 10. Leuven: Peeters.

Albertus Magnus. 1450-1455. Super lohannem. Köln HAStK, Best. 7010, 241, f. 1ra-239v.

Albertus Magnus. 1455. Super Iohannem. Düsseldorf Dominikanerkl. 33, f. 2r-302v.

Albertus Magnus. 1476. Super Iohannem. Emmerich Pfarrarchiv St. Aldegundis 1, Depositum Bistumsarchiv Münster 1243, f. 1r-308r.

Albertus Magnus. 1651. Super Iohannem: Alberti Magni Opera omnia, ed. P. Jammy, Vol. Xla. Lugduni.

Albertus Magnus. 1504-1505. Super lohannem: Postilla apprime magistralis loannis Evangeliare. Venerabilis domini Alberti magni quondam Ratisponensis Episcopi Ordinis Predicatorum, ed. B. Laurentii (Colonia), Rynman et Henricus Gran. Hagenau.

Albertus Magnus. not after 1477. Super lohannem: Venerabilis domini Alberti magni predicatorum ordinis: quondam Ratisponensis episcopi: postilla in euangelium beati lohannis, Johann Guldenschaff. Colonia.

Alfarabius. Fontes quaestionum, ed. Augustus Schmoelders. In Augustus Schmoelders. 1836. Documenta philosophiae Arabum, ex codd. mss. primus edidit, Latine vertit, commentario illustravit. Bonnae. 43-56; 87-323.

Algazel. 1933. Algazel's Metaphysics, ed. J. T. Muckle. St Michael's Medieval Studies 9. Toronto. Aristoteles. 1966. De generatione animalium, transl. G. de Morbeka, ed. H. J. Drossaart Lulofs. Aristoteles Latinus XVII/2.V. Turnhout: Brepols.

Aristoteles. 1986. De generatione et corruptione, transl. vetus, ed. J. Judycka. Aristoteles Latinus IX/1. Leiden: Brill.

Augustinus Hipponensis. 1954. In lohannis evangelium tractatus CXXIV, ed. R. Willems, cura et studio D. R. Willems O. S. B. CCSL XXXVI. Turnhout: Brepols.

Averroes. 1562-1574. Metaphysica. Ed. Veneta VIII. Venetiis (Reprint: 1962. Frankfurt: Minerva). 
Avicebron (Ibn Gebirol). 1892-1895. Fons vitae ex Arabico in Latino translatus ab lohanne Hispano et Dominico Gundissalino, ex codicibus parisinis, amploniano, columbino primum edidit Clemens Baeumker. Beiträge zur Geschichte der Philosophie und Theologie des Mittelalters. Texte und Untersuchungen 1/2-4. Münster.

Avicenna. 1972. Liber de anima seu Sextus de naturalibus I-III, édition critique de la traduction latine médiévale par Simone Van Riet, introduction doctrinale par Gérard Verbeke, vol. 1: I-III. Avicenna Latinus I. Ouvrage publié avec le concours de la Fondation Universitaire de Belgique. Louvain/Leiden: Peeters/Brill.

Avicenna. 1980. Liber de philosophia prima sive scientia divina. Avicenna Latinus, vol. 1: I-IV; vol. 2: V-X, édition critique de la traduction latine médiévale par Simone Van Riet, introduction doctrinale par Gérard Verbeke. Louvain/Leiden: Peeters/Brill.

Echardus Theutonicus. 1936-1989. Expositio sancti Evangelii secundum Iohannem, ed./transl. K. Christ et al. Die lateinischen Werke, vol. III (Indices, ed. L. Sturlese, 1994). Stuttgart: Kohlhammer.

Glossa interlinearis \& marginalis super lohannem, in Biblia latina cum glossa ordinaria. 1603. Tomus V. Venetiis.

Iohannes Damascenus. 1955. De fide orthodoxa. Versions of Burgundio and Cerbanus, ed. E. M. Buytaert. Franciscan Institute Publications. Text Series n. 8. St. Bonaventure (N.Y.), Louvain. Paderborn.

Isidorus Hispalensis. 1850. Etymologiarum sive originum libri XX, ed. J.-P. Migne, Patrologia Latina LXXXII. Parisiis.

Isidorus Hispalensis. 1911. Etymologiarum sive Originum libri XX, ed. W. M. Lindsay. Scriptorum Classicorum Bibliotheca Oxoniensis. Oxonii.

Moses Maimonides. 1520. Dux neutrorum, ed. Augustinus lustinianus. Paris (Reprint: 1964. Francfort).

Ps.-Aristoteles. 1562-1574. De causis proprietatum elementorum, Aristotelis opera omnia cum commentariis Averrois. Ed. Veneta VI. Venetiis (Reprint: 1962. Frankfurt: Minerva).

Ptolemaeus, C. 1515, Almagestum, ed. P. Liechtenstein Coloniensis Germani. Ed. Veneta. Venetiis.

\section{Secondary literature}

Casteigt, Julie. Forthcoming. 'Le Super Iohannem d'Albert le Grand: commenter un témoignage.' In Pascale Bermon, Isabelle Moulin (eds), Actes du colloque international de l'Institut d'Études médiévales de l'Institut Catholique de Paris (ICP): 'Commenter au Moyen-Âge'. Collection de l'Institut d'Études Médiévales de l'Institut Catholique de Paris 5. Paris: Vrin.

Casteigt, Julie. 2014. 'Quelques propositions synthétiques pour une lecture des interprétations albertienne et eckhartienne de In 1, 6-8.' In 'In Principio erat Verbum': Philosophy and Theology in the Commentaries of the Gospel of John (II-XIV Century), ed. F. Amerini. Archa Verbi. Subsidia, vol. 11. Münster. 159-76.

Duhem, Pierre M. M. 1954. Le Système du monde: Histoire des doctrines cosmologiques de Platon à Copernic. Vol. 3. Paris: Hermann et Cie.

Gilson, Étienne. 1998. L’Esprit de la philosophie médiévale. Études de philosophie médiévale. Paris: Vrin. 
Gregory, Tullio. 1996. 'Natura et qualitas planetarum', Micrologus: Natura, scienze, e società medievali 4. 1-23.

Hoßfeld, Paul. 1969. 'Die naturwissenschaftliche/naturphilosophische Himmelslehre Alberts des Grossen (nach seinem Werk De caelo et mundo)', Philosophia naturalis 11/3. 318-29.

Lewis, Charlton T., Short, Charles (revised and elarged by), E. A. Andrews (transl.) and William Freund (1st ed.). 1956. A Latin Dictionary founded on Andrew's edition of the Freund's Latin dictionary. Oxford.

Libera, Alain de. 1990b. 'Albert le Grand et Thomas d'Aquin, interprètes du Liber de causis', Revue des Sciences philosophiques et théologiques 74. 347-78.

Libera, Alain de. 1990a. Albert le Grand et la philosophie. À la recherche de la vérité. Paris: Vrin.

Libera, Alain de. 2005. Métaphysique et noétique: Albert le Grand. Problèmes et controverses. Paris: Vrin.

Price, B. B. 2012. 'Interpreting Albert the Great on Astronomy.' In A Companion to Albert the Great: Theology, Philosophy and the Sciences, ed. I. M. Rescnick. Brill's Companions to the Christian Tradition 38. Leiden: Brill. 396-436.

Stein, Giovanni. 1944. 'S. Alberto Magno e l'Astronomia', Angelicum 21. 182-91.

Thorndike, Lynn. 1949. The Sphere of Sacrobosco and Its Commentators. Chicago: University of Chicago Press. 